\title{
Three mRNA transcripts of the proopiomelanocortin gene in human placenta at term
}

\author{
S I Grigorakis ${ }^{1}$, E Anastasiou ${ }^{1}, \mathrm{~K}$ Dai $^{1}$, A Souvatzoglou ${ }^{1}$ and M Alevizaki ${ }^{1,2}$ \\ ${ }^{1} 1$ st Endocrine Section and ${ }^{2}$ Department of Clinical Therapeutics, Alexandra University Hospital, 11528 Athens, Greece \\ (Correspondence should be addressed to Maria Alevizaki, Endocrine Unit, Department of Clinical Therapeutics, Alexandra University Hospital, \\ 80, Vassilissis Sofias Ave, 11528 Athens, Greece; Email: mani@OTENET.GR)
}

\begin{abstract}
The proopiomelanocortin (POMC) gene whose normal pituitary specific mRNA product is 1200 bases (b) is also expressed in placenta and its peptide derivatives such as ACTH and $\beta$-endorphin may play an important role in the initiation of labor. So far, two mRNA transcripts, one small $(800 \mathrm{~b})$ and one large $(1380 \mathrm{~b})$ have been reported in placenta by Northern blot analysis, similar to other endocrine tissues and various extrapituitary tumors; however, it is questionable whether both of these transcripts are effectively translated to a functional protein. We examined by Northern blot analysis the size and the differential expression of placental POMC gene transcripts in pregnant women with different modes of delivery. Placental tissues were collected from two groups of pregnant women, six with vaginal delivery (VD) and five with cesarean section (CS). In both groups of placentae three POMC gene transcripts were detected of 800,1200 and 1380 bases; the $1200 \mathrm{~b}$ pituitary specific species often predominated and was always present. The $800 \mathrm{~b}$ transcript was also always present, while the large transcript $(1380 \mathrm{~b})$ was expressed in 3/6 VD and 2/5 CS placental tissues. No differences in the relative levels of any of these mRNA species showing effect of the mode of delivery were observed. We conclude that POMC gene transcription in placental tissue at term gives rise to three mRNA transcripts, thus resembling extrapituitary tumors. The reported changes in the levels of the derivative peptides according to the mode of delivery do not reflect changes in POMC mRNA levels and could be attributed to a posttranslational effect.
\end{abstract}

European Journal of Endocrinology 142 533-536

\section{Introduction}

The proopiomelanocortin (POMC) gene is specifically expressed in the corticotroph cells of the anterior pituitary and, at lower levels, in various extrapituitary endocrine tissues such as adrenal medulla (1), ovary, testis and placenta (2). Peptide products such as adrenocorticotropin (ACTH), $\beta$-endorphin ( $\beta$-end), $\alpha$-melanocyte-stimulating hormone, and $\beta$-lipotropin derived from this gene's precursor polyprotein are produced in placenta in the early stages of gestation and at term (3). The pituitary specific mRNA is 1200 bases (b), giving rise to the full precursor polyprotein.

Previous studies in human placentae using Northern blot analysis have identified a POMC gene mRNA transcript about 200 bases shorter than that in the pituitary and hypothalamus, for which there is no evidence as to whether it is functional $(2,4)$, and a small amount of a larger mRNA transcript (1300 to 1500 bases), similar to that detected in various tumor tissues, which is efficiently translated (5). In only one study has pituitary-like $(1200 \mathrm{~b})$ POMC gene mRNA expression been reported in placental tissue (6), presumably at very low levels. In addition, there are contradictory data concerning the level of expression of POMC gene in placenta at term according to the mode of delivery (7-9).

In this study, we undertook to evaluate the expression of the POMC gene at the transcription level in placental tissue of pregnant women at term undergoing different modes of delivery.

\section{Materials and methods}

Placentae were collected from two different groups of pregnant women at term. First, from six pregnant women after vaginal delivery (VD). Four of them had delivered after induction of labor using oxytocin (VDox). Secondly, from five women after elective cesarian section (CS). All pregnant women were healthy and gestational age at delivery was between 37 and 41 weeks.

Longitudinally cut strips, containing the full thickness of each placenta were frozen in liquid nitrogen and kept at $-70^{\circ} \mathrm{C}$ until further analysis. Total RNA was extracted with the guanidinium isothiocyanate/ acid phenol method. The samples were enriched in 
polyadenylated RNA using oligo-dT cellulose affinity chromatography. Polyadenylated RNA (poly A) was quantified by optical density (OD) absorption at $260 \mathrm{~nm}$ and was size separated by electrophoresis in a $1.4 \%$ agarose gel including RNA molecular markers (Gibco/ BRL, Paisley, UK). Poly A RNA (11-24 $\mu \mathrm{g})$ was analyzed by Northern blotting using a POMC specific probe corresponding to the coding region of the third exon of the respective gene (probe Phox3A) (6). Pituitary ACTH-secreting adenoma cells were used as a positive control as well as a molecular marker for the pituitary specific (1200 b) transcript.

To correct for the amount of RNA analyzed and evaluate the relative level of POMC expression, a ubiquitin specific probe was also used. The relative levels of POMC and ubiquitin expression were quantified by absorbance measurements on autoradiograms. These measurements were expressed as the ratio of densitometric units of POMC to ubiquitin RNA. Comparisons were performed by non-parametric tests (Wilcoxon).

\section{Results}

\section{Northern blot analysis}

POMC gene expression was detected in all placental tissues of the two groups of women after three days of film exposure at $-90^{\circ} \mathrm{C}$. Three different mRNA species were present in the samples, estimated at 1380, 1200 and 800 bases (Fig. 1). There was considerable

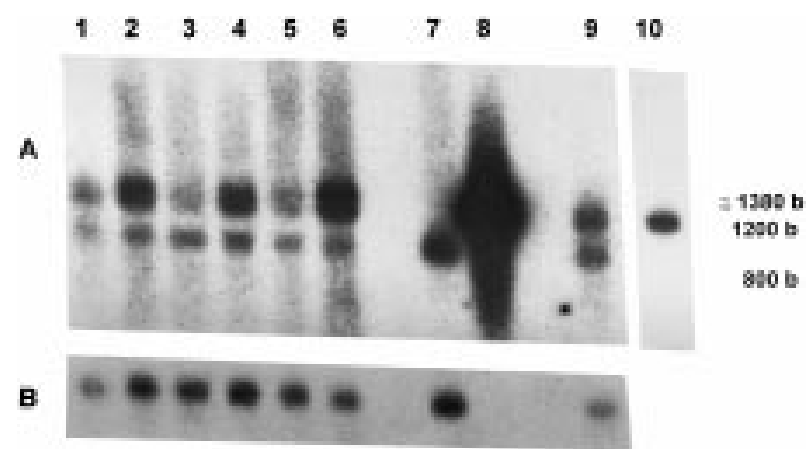

Figure 1 Northern blot analysis of polyadenylated $\left(\mathrm{pA}^{+}\right) \mathrm{RNA}$ $(11-24 \mu \mathrm{g})$ extracted from human placenta. The $1380 \mathrm{~b}$ (estimated using RNA molecular markers) and $1200 \mathrm{~b}$ species migrate close together; however the larger species is absent from the pituitary cells and pancreas samples, as well as from placentae in lanes 1 and 3. Lanes 1-4: placental samples obtained after vaginal delivery; lanes 5-6: samples obtained after cesarian section. Similar RNA species variability was observed in a further five samples (not shown). Lane 7: pA ${ }^{+}$RNA $(20 \mu \mathrm{g})$ from acute lymphoblastic leukemia lymphocytes (only the smaller species is present). Lane 8: total RNA $(0.5 \mu \mathrm{g})$ from ACTH-secreting pituitary adenoma. Lane 9: $5 \mu \mathrm{g} \mathrm{pA}{ }^{+}$RNA from normal human pancreas; the 1200 and 800 species are present (pancreatic expression of POMC gene has not been reported previously). Lane 10: shorter exposure of the same blot. Only the pituitary tissue sample (lane 8 ) is shown. (A) POMC specific probe. (B) The same blot probed with a ubiquitin specific probe. variability in the mRNA species between samples. The 1200 or $800 \mathrm{~b}$ species predominated in most of the cases. In all placentae in both groups both the 800 and $1200 \mathrm{~b}$ transcripts were expressed. The $1380 \mathrm{~b}$ transcript was expressed in 3/6 VD placentae and in 2/5 CS placentae (not all data are shown but are available on request). The $1200 \mathrm{~b}$ species, which is the pituitary-like species, predominated in 7/11 of the cases and was always present.

The POMC/ubiquitin ratio did not differ between the VD and CS groups of women for any of the three POMC transcripts (Table 1). No significant effect of gestational age or oxytocin administration (although this only concerned two patients) could be demonstrated.

\section{Discussion}

We demonstrated three mRNA transcripts (1380, 1200 and 800 bases) in almost all placental tissues, the pituitary-like one (1200 b) being always present. So far, a small species (800-900 b) and low levels of a large (up to $1500 \mathrm{~b}$ ) species have been detected in this tissue and other extrapituitary or tumor tissues $(2,5)$. Surprisingly, placental expression of the $1200 \mathrm{~b}$ POMC gene transcript has not been reported by Northern blot analysis and has only been detected in some cases when more sensitive techniques were used (6). It is possible that this abundant expression of the $1200 \mathrm{~b}$ variant became obvious because we analyzed many samples and used a large amount of poly A mRNA. Our finding is consistent with the importance of POMC expression in placenta. From our data we are not able to conclude which particular cells of placenta express different POMC transcripts at term; however, Cooper et al. (7) using in situ hybridization have shown that ACTH is detected in syncytiotrophoblast cells during the second and third trimesters, which suggests that this should be a site of production of the full-length mRNA species.

Table 1 POMC to ubiquitin optical density ratios for the three POMC mRNA species obtained from the respective autoradiograms of human placentae analyzed by Northern blotting. Values are means \pm S.D. The figures in parentheses indicate range of $\mathrm{OD}$ values.

\begin{tabular}{lcc}
\hline POMC mRNA species & $\begin{array}{c}\text { Cesarian section } \\
(n=5)\end{array}$ & $\begin{array}{c}\text { Vaginal delivery } \\
(n=6)\end{array}$ \\
\hline $1380 \mathrm{~b}$ & $0.61 \pm 0.42$ & $0.69 \pm 0.33$ \\
& $(0.28-1.34)$ & $(0.38-0.83)$ \\
$1200 \mathrm{~b}$ & $0.67 \pm 0.41$ & $0.89 \pm 0.30$ \\
& $(0.28-1.34)$ & $(0.53-1.1)$ \\
$800 \mathrm{~b}$ & $0.61 \pm 0.18$ & $0.73 \pm 0.24$ \\
& $(0.38-0.81)$ & $(0.52-0.9)$
\end{tabular}

No differences in the OD ratios were observed between the cesarian section and the vaginal delivery groups (Wilcoxon test). 
In five out of eleven placental tissues we detected the $1380 \mathrm{~b}$ POMC gene transcript. Large POMC gene transcripts $(\sim 1350 \mathrm{~b}, \sim 1450 \mathrm{~b})$, which are probably translated to POMC peptide products, have also been found in other endocrine tissues such as the testis, ovary, and adrenal $(2,5)$ as well as in large proliferating extrapituitary tumors such as small cell lung carcinoma $(4,10,11)$. In addition, the large species is also abundant in metastases of medullary thyroid carcinoma, often while absent from the primary tumor, indicating that its presence may be associated with high cell proliferation (12). In this respect, it is interesting that besides ACTH production the placenta also shares some other features with non-pituitary tumors such as invasiveness, proliferation and autonomous secretion $(13,14)$.

On the other hand, it is unlikely that the small transcripts that we constantly detected have any biological function (5), as this short (800 nt) mRNA lacks the coding region for the signal peptide sequence (6); in theory, however, it could be effectively translated in the cytotrophoblast through an, as yet, unknown mechanism, since one out of two reading frames of this mRNA can generate $\beta$-end. POMC gene products such as ACTH and $\beta$-end could be produced in placenta either by the 'normal pituitary' or the large $(1380 \mathrm{~b})$ transcripts, through a differential processing mechanism.

This study confirms previous studies showing that the mode of delivery, VD (spontaneous or induced) or CS, did not affect the POMC expression in placenta (7). POMC gene products, ACTH and $\beta$-end, have been implicated in the initiation of parturition (15). They affect both the hypothalamic-pituitary-adrenal axes of the mother and fetus and are also related to the stress of vaginal delivery. So far, only $\beta$-end levels have been found to be higher in placental extracts collected after VD compared with CS (8). However, it seems that POMC transcript levels are not the main determinant of placental $\beta$-endorphin levels at term.

Oxytocin, which was used for the induction of labor, did not appear to affect POMC expression in placenta in our experiment, which is in agreement with others using immunocytochemistry (7). On the contrary, oxytocin probably increases the release of POMC peptides, as has been shown by previous in vitro experiments (16).

From our data no convincing explanation can be offered for the wide variation in the molecular size and level of expression of the POMC gene in placenta. Further experiments using reverse transcriptionpolymerase chain reaction and transfection studies will be needed to clarify whether a variable splicing event or an alternative mode of transcription initiation is responsible for this tissue specific size polymorphism, as has already been suggested $(5,6)$. It is important that studies are carried out which will explore the mechanisms of the tissue specific regulation of transcription of the human POMC gene.
In conclusion, it seems that in placenta an 'abnormal' POMC gene transcription takes place, such as occurs in ACTH-producing non-pituitary tumors, which may be related to the tissue specific activity of the POMC gene promoter (17). Our results imply that if these local POMC gene products in placenta are related to the parturition process, this might be a post-translational effect.

\section{References}

1 Jingami H, Nakanishi S, Imura H \& Numa S. Tissue distribution of messenger RNAs coding for opioid peptide precursors and related RNA. European Journal of Biochemistry 1984142 441-447.

2 Chen C-LC, Chang C-C, Krieger DT \& Bardin CW. Expression and regulation of proopiomelanocortin-like gene in the ovary and placenta: comparison with the testis. Endocrinology 1986118 2382-2389

3 Laatikainen T, Saijonmaa O, Salminen K \& Wahlstrom T. Localization and concentrations of beta-endorphin and betalipotropin in human placenta. Placenta 19878 381-386.

4 Texier P-L, de Keyzer Y, Lacave R, Vieau D, Lenne F, Rojas-Miranda A et al. Proopiomelanocortin gene expression in normal and tumoral human lung. Journal of Clinical Endocrinology and Metabolism 199173 414-420.

5 DeBold CR, Nicholson WE \& Orth DN. Immunoreactive proopiomelanocortin (POMC) peptides and POMC-like messenger ribonucleic acid are present in many rat non-pituitary tissues. Endocrinology 1988122 2648-2657.

6 Lacaze-Masmonteil T, de Keyzer Y, Luton J-P, Kahn A \& Bertagna X. Characterization of proopiomelanocortin transcripts in human nonpituitary tissues. Proceedings of the National Academy of Sciences of the USA 198784 7261-7265.

7 Cooper ES, Greer IA \& Brooks AN. Placental proopiomelanocortin gene expression, adrenocorticotropin tissue concentrations, and immunostaining increase throughout gestation and are unaffected by prostaglandins, antiprogestins, or labor. Journal of Clinical Endocrinology and Metabolism $1996814462-$ 4469.

8 Facchinetti F, Garuti G, Petraglia F, Mercantini F \& Genazzani AR. Changes in $\beta$-endorphin in fetal membranes and placenta in normal and pathological pregnancies. Acta Obstetrica Gynecologica Scandinavica $199069603-607$.

9 Petraglia F, Florio P, Nappi C \& Genazzani AR. Peptide signaling in human placenta and membranes: autocrine, paracrine, and endocrine mechanisms. Endocrine Reviews 199617 156186.

10 Clark AJL, Lavender PM, Besser GM \& Rees LH. Proopiomelanocortin mRNA size heterogeneity in ACTH secreting tumours. Journal of Molecular Endocrinology 19892 3-9.

11 Hoppener JWM, Steenbergh PH, Moonen PJJ, Wagenaar SjSc, Jansz HS \& Lips CJM. Detection of mRNA encoding calcitonin, calcitonin gene related peptide and proopiomelanocortin in human tumors. Molecular and Cellular Endocrinology 198647 125-130.

12 de Keyzer Y, Bertagna X, Lenne F, Girard F, Luton J-P \& Kahn A. Altered proopiomelanocortin gene expression in adrenocorticotropin-producing nonpituitary tumors. Journal of Clinical Investigation $1985761892-1898$.

13 Tropper PJ, Goland RS, Wardlaw SL, Fox HE \& Frantz AG. Effects of betamethasone on maternal plasma corticotropin releasing factor, ACTH and cortisol during pregnancy. Journal of Perinatal Medicine 198715 221-225.

14 Genbacev O, Zhou Y, Ludlow JW \& Fisher SJ. Regulation of human placental development by oxygen tension. Science 1997 277 1669-1672. 
15 Challis J, Matthews S, Van Meir C \& Ramirez M. Current topic: the placental corticotrophin-releasing hormone-adrenocorticotrophin axis. Placenta $199516481-502$.

16 Margioris AN, Grino M, Protos P, Gold PW \& Chrousos GP. Corticotropin-releasing hormone and oxytocin stimulate the release of placental proopiomelanocortin peptides. Journal of Clinical Endocrinology and Metabolism 198866 922-926.
17 Jeannotte L, Trifiro MA, Plante RK, Chamberland M \& Drouin J. Tissue-specific activity of the proopiomelanocortin gene promoter. Molecular Cellular Biology 1987 7 4058-4064.

Received 29 September 1999

Accepted 15 January 2000 